\title{
The higher returns to formal education for entrepreneurs versus employees in Australia ${ }^{\text {th }}$
}

\author{
Jolanda Hessels $^{\text {a, }}$, Cornelius A. Rietveld ${ }^{\text {a,b }}$, A. Roy Thurik ${ }^{\text {a,b,c }}$, Peter van der Zwan ${ }^{\text {d }}$

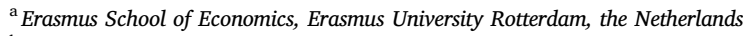 \\ ${ }^{\mathrm{b}}$ Erasmus University Rotterdam Institute for Behavior and Biology (EURIBEB), Erasmus University Rotterdam, the Netherlands \\ ${ }^{\mathrm{c}}$ Montpellier Business School, France \\ ${ }^{\mathrm{d}}$ Department of Business Studies, Leiden Law School, Leiden University, the Netherlands
}

\section{A R T I C L E I N F O}

Keywords:
Entrepreneurship
Self-employment
Education
Income
Job control
Earnings
JEL codes:
J24
J31
L26

\begin{abstract}
A B S T R A C T
Van Praag et al. (2013) analyze whether the returns to formal education in terms of income differ between entrepreneurs and employees. Using US data (1979-2000), they find that entrepreneurs have higher returns to formal education than employees. They also find evidence that the level of personal control in one's occupation explains these higher returns. In the present study, we aim to replicate these findings using a dataset from a different country (Australia) and time period (2005-2017). Moreover, we extend the study by Van Praag et al. (2013) by distinguishing between entrepreneurs with and without employees. In accordance with Van Praag et al. (2013), we also find higher returns to education for entrepreneurs compared to employees. However, this finding mainly applies to the entrepreneurs without employees. Moreover, we do not find evidence for a mediating role of personal control in this relationship.
\end{abstract}

\section{Introduction}

The study by Van Praag et al. (2013) is an important contribution to the literature on the returns to formal education for its comparison of these returns (in terms of income) between entrepreneurs and employees. The empirical analyses in this study indicate that the relation between formal education and income is stronger in entrepreneurship than in wage work and also suggest that the higher level of personal control in one's job partly explains these higher returns. As three major implications of these results, the authors argue that it seems value enhancing "to stimulate people with higher levels of formal education to become entrepreneurs", "to stimulate people who wish to become entrepreneurs to go to school first", and that "an avenue of organizing towards more value creation seems the assignment of more control to workers" (Van Praag et al., 2013, p. 393).

In the present study, we analyze whether the education premium for entrepreneurs and the important role for perceived control are also present in a different country (Australia instead of the United States of America) and in a more recent time period (2005-2017 instead of 1979-2000). Hence, the primary aim of the present study is to replicate the findings of Van Praag et al. (2013). In doing so, we implement two important changes as compared to the set-up used by Van Praag et al. (2013). First, to proxy control in one's job, we employ a multi-item measure of an individual's level of autonomy at the workplace rather than locus of control in general because the

\footnotetext{
Pre-registered replication plan available online at https://osf.io/93xjp/.

* Corresponding author. Department of Applied Economics, Erasmus School of Economics, Erasmus University Rotterdam, P.O. Box 1738, 3000 DR, Rotterdam, the Netherlands.

E-mail address: hessels@ese.eur.nl (J. Hessels).
} 
former measure relates more directly to the theoretical mechanism put forward by Van Praag et al. (2013). Second, we distinguish between entrepreneurs with and without employees because the skillset they require to run their business successfully differs (Lazear, 2005; Hébert and Link, 2009).

The set-up of the present study is as follows. In the next section we formulate the hypotheses. In the third section, we deal with data and method. In section four, we present the empirical results. Our final section concludes by comparing the results of the present study with those of Van Praag et al. (2013).

\section{Theoretical background}

Van Praag et al. (2013) provide six arguments for why higher returns to formal education in terms of income for entrepreneurs as compared to employees can be expected. In short, returns to education may be estimated to be higher for entrepreneurs as compared to employees because of (a) the risk premium in entrepreneurship (higher educated people requiring a higher risk premium in entrepreneurship); (b) income underreporting by entrepreneurs (depending on their level of education); (c) income misreporting by entrepreneurs (for example due to in- or exclusion of business capital increment); (d) occupational bias (some high-earnings professional workers - such as accountants and medical doctors - are often entrepreneurs); (e) a combination of differential education distributions for entrepreneurs and employees with non-linearities in returns; and (f) a higher level of personal control in entrepreneurship (entrepreneurs can more easily adapt their production activities such that they yield higher returns to their assets). In their empirical analyses, Van Praag et al. (2013) only find support for explanation (f).

In the present study, we follow Van Praag et al. (2013) in extensively analyzing whether the higher returns to formal education for entrepreneurs compared to employees can be explained by personal control at one's job (job control). We expect that (i) the income generated by an additional unit of education is higher for entrepreneurs than for employees, and (ii) the income generated by an additional unit of education is expected to be equal for entrepreneurs and employees if adequately controlled for the level of job control. Therefore, our two hypotheses are:

Hypothesis 1. The returns to formal education in terms of income are higher for entrepreneurs than for employees.

Hypothesis 2. The higher returns to formal education in terms of income for entrepreneurs compared to employees are explained by the level of control in one's job.

We supplement the original analyses in Van Praag et al. (2013) by distinguishing between entrepreneurs with and without employees. The income profiles of these two types of entrepreneurs differ considerably. On average, entrepreneurs without employees earn less than employees, while entrepreneurs with employees earn more than employees (Sorgner et al., 2017). Although both groups of entrepreneurs experience similar levels of job control (Hessels et al., 2017), the presence of others in the organization will make returns to formal education of the entrepreneur in terms of income less straightforward for entrepreneurs with employees than for entrepreneurs without employees. When those with employees make decisions about how to use their own human capital, they need to consider the human capital of others in the organization as well. As a consequence, the income generated by an additional unit of education may be lower for entrepreneurs with employees than for entrepreneurs without employees. On the other hand, education may not only positively affect the entrepreneur's income level, but also boost team performance. As a result, there may be a synergetic advantage of formal education when employing others, possibly through better recognizing and exploiting the skills and talents of employees. We abstain from formulating an explicit hypothesis about possible differential returns to education for entrepreneurs with and without employees, because of the a priori ambiguity of the direction of this relationship. Instead, we perform an exploratory analysis to be replicated in future studies.

\section{Data and methodology}

\subsection{Sample}

We use longitudinal data from the Household, Income and Labor Dynamics in Australia (HILDA) Survey (2005-2017). HILDA is a household-based panel study representative for the Australian population (Watson and Wooden, 2012). Because of the panel structure of these data, we have repeated measures for our variables for a maximum period of 13 years. In total, we use 92,591 person-year observations from 16,293 workers (entrepreneurs/employees) between 16 and 64 years. Hence, on average, each individual in the analysis contributes almost 6 person-year observations. For comparison, Van Praag et al. (2013) analyze approximately 66,000 person-year observations from 5600 entrepreneurs/employees (on average, a little more than 11 person-year observations per individuals).

\subsection{Variables}

Dependent variable. As our dependent variable we use Gross Labor Income, that is, the sum of an individual's gross wage/salary income and his/her business income per year. Person-year observations with negative and zero incomes are not considered. In our model specifications we use the logarithmic transformation of the income variable.

Independent variables. Our measure of entrepreneurship is similar to the one employed by Van Praag et al. (2013), and includes individuals who are self-employed or who own/direct an incorporated business. Specifically, the HILDA questionnaire asks individuals whether, at any time at all during the last 7 days, they "work[ed] for an employer for wages or salary", whether they "work[ed] in your 
own business with employees", or "work[ed] in your own business without employees". Hence, this question also enables to distinguish between entrepreneurs without employees (zero employees) and with employees (at least one employee). A follow-up question asks about the incorporation status of the business. Our variable Entrepreneur takes value 1 if an individual is the owner of an (un)incorporated business, and value 0 if an individual has a salaried job. The entrepreneurship variable refers to the main employment status. ${ }^{1}$ Similar to Van Praag et al. (2013), "hobby entrepreneurs" are excluded from the analysis. That is, we take only account of entrepreneurs working at least $300 \mathrm{~h}$ per year. Moreover, again following Van Praag et al. (2013), we exclude the "farmers and farm managers" from our sample using the 2-digit ANZSCO 2006 occupation classification available in HILDA. ${ }^{3}$ Like Van Praag et al. (2013), we measure the respondent's education level in years of completed schooling. We follow Leigh and Ryan (2005, 2008) - also using the HILDA data with our definition of the variable Education. It combines information about the highest year of school an individual completed (usually some year in secondary school) and the highest post-school qualification an individual has obtained (usually in higher education). Our variable Education ranges from eight to seventeen years of schooling. ${ }^{4} \mathrm{Job}$ control is measured by the level of decision authority in one's job. The following three items have been used to calculate an average (Cronbach's alpha =0.83): (a) "I have a lot of freedom to decide when I do my work," (b) "I have a lot of say about what happens on my job," and (c) "I have a lot of freedom to decide how I do my own job." A seven-point scale was used for answering ( $1=$ strongly disagree to $7=$ strongly agree). These items have been included jointly in various earlier studies (Smith et al., 1997; Karasek et al., 1998; DiRenzo et al., 2011; Wu, 2016; Hessels et al., 2017). Job control has been standardized to have mean 0 and standard deviation 1 in the analysis sample, and higher values reflect a higher level of job control.

Control variables. We follow Van Praag et al. (2013) in our selection of control variables. First, we control for age, cohort and time effects. That is, we add age (in years) and cohort dummies to the model specifications and transformed wave dummies are included following Deaton (2000). In addition, we include a dummy variable for gender (Male $=1$; Female $=0$ ) and marital status (Currently Married = 1; Not Married = 0; respondents in de-facto relationships are coded as married). For health status, we use self-assessed health ("In general, how would you say your health is?"; 1 if Fair or Poor is answered; 0 if Excellent/Very Good/Good is answered). Parental education levels are included in our model specifications as well. These variables are based on "How much schooling did your father/mother complete?" and "Did your father/mother complete an educational qualification after leaving school?". The codes are as follows: 1 = None; $2=$ Primary School only; $3=$ Secondary School; $4=$ Year 11 or Equivalent; $5=$ Year 12 of equivalent; $6=$ Higher education. We also control for the geographical location the respondent lives, by including dummy variables for eight states: Australian Capital Territory, New South Wales, Northern Territory, Queensland, South Australia, Tasmania, Victoria, and Western Australia. ${ }^{5}$ We also include a dummy variable for whether someone was born in Australia (value 1 ) or not (value 0 ). ${ }^{6}$ The number of hours worked per week is included in all model specifications.

Finally, we include a measure for cognitive ability. We make use of scores related to a Backward Digit Span test in which respondents repeat numbers in reverse order that were read out to them, a Symbol Digits Modalities test in which participants match symbols to numbers, and the National Adult Reading Test (Short-Form; NART25) in which respondents read out words. These tests were included in the 2012 and 2016 questionnaires of the HILDA survey (Wooden, 2013). If an individual took part in 2012 and 2016, we take the average score. We remove age and education effects, in line with Van Praag et al. (2013), by regressing the test scores on age and education dummies (for variation across age and education, see also Wooden (2013)). Thereafter, we performed a factor analysis on the standardized residuals. The resulting factor scores are included as a control variable in some of our model specifications (see Hartog et al. (2010) for a similar procedure). In our analyses, we assume cognitive ability to be generally stable between 16 and 64 years of age.

\subsection{Empirical strategy}

We follow the estimation procedure of Van Praag et al. (2013), and focus on the analyses presented in Tables 3 and 5 in Van Praag et al. (2013). This means that we abstain from reporting the results of an instrumental variable regression with parental household characteristics as instrumental variables, because these instrumental variables most likely violate the exclusion restriction of instrumental variable analysis. ${ }^{7}$

When explaining Gross Labor Income, we first restrict our sample to entrepreneurs to estimate the returns to education for this subsample. We are interested in the coefficient of the variable Education (cf. specification 1, Table 3A in Van Praag et al., 2013). Next, we perform the same regression for the employees (cf. specification 2, Table 3A in Van Praag et al., 2013). Subsequently, we analyze the

\footnotetext{
${ }^{1}$ In HILDA this is retrieved in the questionnaire as follows: "If respondent says they work in more than one job, code in respect of the job that they get the most pay from."

2 Australian and New Zealand Standard Classification of Occupations.

${ }^{3}$ This exclusion is motivated by the fact that the nature of entrepreneurship in agriculture is different from the nature of entrepreneurship in other sectors (Grande et al., 2011).

${ }^{4}$ The highest number of years of schooling completed is $8,9,10,11$, or 12 years; 7 or fewer years is coded as 8 years, “... since it is only separately identified for respondents in certain states" (Leigh and Ryan, 2005, p. 21). Regarding the highest educational level achieved (post-school qualification), years of schooling is coded as follows: postgraduate degree $=17$, graduate diploma/certificate $=16$, bachelor's degree $=15$, advanced diploma/diploma/certificate $=12$.

${ }^{5}$ Van Praag et al. (2013) capture the geographical location a respondent lives with the variables "Live outside big city" and "Live in the South of US".

${ }^{6}$ Ethnicity, included as a control variable in Van Praag et al. (2013), is not available in HILDA.

${ }^{7}$ In addition, some parental household characteristics used by Van Praag et al. (2013) are not available in our dataset (such as the availability of magazines and library cards in the parental household).
} 
combined sample including an interaction term between the variables Education and Entrepreneur. The coefficient of the interaction term indicates the possible different returns to education between entrepreneurs and employees (cf. specification 3, Table 3A in Van Praag et al., 2013).

Following Van Praag et al. (2013) we estimate specifications 1, 2, 3 using random effects regressions to capture the panel structure of our dataset. We also perform a fixed effects regression that controls for unobserved, time-constant effects and exploits the variation over time within individuals (cf. specification 4, Table 3A in Van Praag et al., 2013). Cluster-robust standard errors are used throughout. All these specifications include the control variables described in the previous section. In addition to the interaction between Education and Entrepreneur, specifications 3 and 4 also include the interactions between Entrepreneur and all control variables, in line with Van Praag et al. (2013). The regressions corresponding to specifications 1, 2, 3 and 4 are performed both without cognitive ability (cf. Table $3 \mathrm{~A}$ in Van Praag et al., 2013) and with cognitive ability (cf. Table 3B in Van Praag et al., 2013).

We expect job control to explain the higher returns to education for entrepreneurs compared to employees. Hence, we test for mediated moderation, that is, the extent to which our mediating variable - job control - explains the significance of the interaction term Education $\times$ Entrepreneur. To test Hypothesis 2, we use the procedure for assessing mediated moderation as described in Fairchild and MacKinnon (2009) which is also used in Van Praag et al. (2013). This means that we are specifically interested in the reduction of the coefficient of the interaction term Education $\times$ Entrepreneur after adding job control to our model specification. Fairchild and MacKinnon (2009) do not only add the interaction Job control $\times$ Entrepreneur to the model but they also stress the importance of adding the Job control $\times$ Education interaction “... to avoid bias in the XZ term ..." (p. 11), where X refers to Education and Z refers to Entrepreneur. Therefore, the triple interaction Education $\times$ Job control $\times$ Entrepreneur is also added to our model specifications, in line with Fairchild and MacKinnon (2009) and Van Praag et al. (2013).

Table 1

Descriptive statistics of the analysis sample.

\begin{tabular}{|c|c|c|c|c|c|c|c|c|}
\hline & \multicolumn{2}{|l|}{ All } & \multicolumn{2}{|c|}{ Entrepreneurs without employees } & \multicolumn{2}{|c|}{ Entrepreneurs with employees } & \multicolumn{2}{|c|}{ Wageworkers } \\
\hline & Mean & SD & Mean & SD & Mean & SD & Mean & SD \\
\hline Gross labor income (ln) & 10.60 & 1.01 & 10.38 & 1.15 & 10.95 & 0.98 & 10.60 & 1.00 \\
\hline Education & 12.87 & 2.08 & 12.69 & 2.08 & 12.97 & 2.11 & 12.87 & 2.08 \\
\hline Job control & 0.00 & 1.00 & 0.91 & 0.80 & 1.07 & 0.68 & -0.13 & 0.96 \\
\hline Cognitive ability & 0.15 & 0.62 & 0.15 & 0.63 & 0.14 & 0.62 & 0.15 & 0.62 \\
\hline Age & 38.82 & 12.99 & 44.55 & 11.39 & 45.79 & 10.03 & 37.96 & 13.03 \\
\hline Hours worked per week & 36.77 & 14.31 & 37.12 & 16.08 & 45.16 & 15.86 & 36.23 & 13.90 \\
\hline Gender $($ Male $=1)$ & 0.50 & 0.50 & 0.63 & 0.48 & 0.68 & 0.47 & 0.48 & 0.50 \\
\hline Married (=1) & 0.68 & 0.47 & 0.76 & 0.42 & 0.89 & 0.31 & 0.66 & 0.47 \\
\hline Not healthy $(=1)$ & 0.09 & 0.29 & 0.10 & 0.31 & 0.09 & 0.28 & 0.09 & 0.29 \\
\hline \multicolumn{9}{|l|}{ Education father } \\
\hline None & 0.01 & 0.08 & 0.01 & 0.09 & 0.01 & 0.11 & 0.01 & 0.07 \\
\hline Primary & 0.08 & 0.27 & 0.11 & 0.31 & 0.12 & 0.33 & 0.08 & 0.27 \\
\hline Some secondary & 0.21 & 0.41 & 0.22 & 0.42 & 0.22 & 0.41 & 0.21 & 0.41 \\
\hline Secondary low & 0.03 & 0.18 & 0.03 & 0.16 & 0.04 & 0.19 & 0.03 & 0.18 \\
\hline Secondary high & 0.07 & 0.25 & 0.05 & 0.22 & 0.06 & 0.23 & 0.07 & 0.25 \\
\hline Post-secondary & 0.60 & 0.49 & 0.58 & 0.49 & 0.55 & 0.50 & 0.60 & 0.49 \\
\hline \multicolumn{9}{|l|}{ Education mother } \\
\hline None & 0.01 & 0.09 & 0.01 & 0.12 & 0.02 & 0.14 & 0.01 & 0.09 \\
\hline Primary & 0.08 & 0.27 & 0.09 & 0.29 & 0.10 & 0.30 & 0.07 & 0.26 \\
\hline Some secondary & 0.31 & 0.46 & 0.31 & 0.46 & 0.35 & 0.48 & 0.31 & 0.46 \\
\hline Secondary low & 0.07 & 0.25 & 0.07 & 0.26 & 0.07 & 0.26 & 0.07 & 0.25 \\
\hline Secondary high & 0.10 & 0.31 & 0.11 & 0.31 & 0.10 & 0.30 & 0.10 & 0.31 \\
\hline Post-secondary & 0.43 & 0.49 & 0.41 & 0.49 & 0.35 & 0.48 & 0.44 & 0.50 \\
\hline \multicolumn{9}{|l|}{ Living in territory } \\
\hline ACT & 0.03 & 0.16 & 0.02 & 0.12 & 0.02 & 0.13 & 0.03 & 0.16 \\
\hline NSW & 0.29 & 0.45 & 0.30 & 0.46 & 0.28 & 0.45 & 0.29 & 0.45 \\
\hline NT & 0.01 & 0.09 & 0.01 & 0.09 & 0.01 & 0.09 & 0.01 & 0.09 \\
\hline QLD & 0.21 & 0.41 & 0.23 & 0.42 & 0.19 & 0.39 & 0.21 & 0.41 \\
\hline SA & 0.09 & 0.28 & 0.08 & 0.28 & 0.09 & 0.29 & 0.09 & 0.28 \\
\hline TAS & 0.03 & 0.17 & 0.02 & 0.14 & 0.02 & 0.15 & 0.03 & 0.17 \\
\hline VIC & 0.26 & 0.44 & 0.25 & 0.43 & 0.26 & 0.44 & 0.26 & 0.44 \\
\hline WA & 0.09 & 0.29 & 0.10 & 0.30 & 0.13 & 0.34 & 0.09 & 0.28 \\
\hline Born in Australia $(=1)$ & 0.81 & 0.39 & 0.75 & 0.44 & 0.76 & 0.43 & 0.82 & 0.39 \\
\hline Observations & 92,591 & & 6252 & & 4921 & & 81,411 & \\
\hline Individuals & 16,293 & & 2162 & & 1431 & & 15,174 & \\
\hline
\end{tabular}

Notes: The number of person-year observations in the column "All" is not exactly the sum of the numbers in the other columns due to some missing values for the question about having employees or not. The number of individuals for "All" does not equal the sum of the numbers in the remaining columns, because some individuals have been both an entrepreneur, with or without employees, and/or an employee in the period 2005-2017. The total number of observations for job control equals 90,324, and for cognitive ability 81,063. 


\section{Results}

\subsection{The returns to education}

Table 1 shows the descriptive statistics of our analysis sample. In total, we make use of 92,591 person-year observations from 16,293 individuals between 16 and 64 years of age. For Gross Labor Income, the means confirm that entrepreneurs without employees earn less than employees, and that entrepreneurs with employees earn more than employees (Sorgner et al., 2017). As in Van Praag et al. (2013), the level of education is comparable for entrepreneurs (both with and without employees) and employees. As expected, the level of job control is much higher for entrepreneurs compared to employees and rather similar for the two types of entrepreneurs (although a bit higher for those with employees).

Table 2 provides the results of a random-effects regression with Gross Labor Income as the dependent variable, both without (panel A) and with (panel B) the cognitive ability measure included as control variable. Column 1 of Table 2 (panel A) shows that each additional year of education increases income by $9.1 \%$ for entrepreneurs. These returns to education equal $6.0 \%$ for employees (Column 2, panel A). Compared to the results of Van Praag et al. (2013), our estimate for employees is similar while our estimate for entrepreneurs is higher: $9.1 \%$ compared to $6.4 \%$. In the full sample (entrepreneurs and employees), we focus on the coefficient of the interaction term between Entrepreneur and Education. We find significantly higher returns to education, 2.2\%-points, for entrepreneurs compared to employees (Column 3, panel A). Hence, compared to the 1.6\%-points found by Van Praag et al. (2013), our estimate is about 1.5 times higher. The results of the fixed-effects regression in column 4, panel A, reveal a premium of $2.4 \%$-points for entrepreneurs, which is similar to the fixed-effects premium as reported by Van Praag et al. (2013). From a qualitative point of view, and as in Van Praag et al. (2013), the inclusion of cognitive ability as a control variable does not change the results (panel B). Hence, Hypothesis 1 is supported.

\subsection{Explaining the returns to education}

Column 1 in Table 3 (panel A) shows the results of a random-effects regression in which job control and the interaction terms as described in Section 3.3 are added. We do not observe a reduction of the interaction term Education $\times$ Entrepreneur. A similar observation can be made for the fixed-effects specification, and for the results in panel B. Hence, we do not find evidence for mediated moderation and no support for Hypothesis 2.

\subsection{Entrepreneurs with and without employees}

Table 4 distinguishes between entrepreneurs without employees and entrepreneurs with employees. In column 1 , the results are shown for the entrepreneurs without employees and in column 2 for those with employees (random-effects specifications). In columns 3 (random-effects) and 4 (fixed-effects), the interaction terms Education $\times$ Entrepreneur without employees and Education $\times$ Entrepreneur with employees are added. In panel A of Table 4, we observe significantly higher returns to education for the entrepreneurs without employees compared to employees (difference of 2.7 percentage-points in the random-effects specification, and

Table 2

The relationship between formal education and income (dependent variable: logarithm of annual income).

\begin{tabular}{|c|c|c|c|c|}
\hline & $\begin{array}{l}\text { (1) } \\
\text { Entrepreneurs (RE) }\end{array}$ & $\begin{array}{l}(2) \\
\text { Employees (RE) }\end{array}$ & $\begin{array}{l}\text { (3) } \\
\text { All (RE) }\end{array}$ & $\begin{array}{l}\text { (4) } \\
\text { All (FE) }\end{array}$ \\
\hline \multicolumn{5}{|c|}{ A. Cognitive ability not included } \\
\hline Education & $0.091(0.009)^{* * *}$ & $0.060(0.003)^{* * *}$ & $0.061(0.003)^{* * *}$ & \\
\hline Entrepreneur & & & $-1.219(0.522)^{* *}$ & $-0.554(0.188)^{* * *}$ \\
\hline Education $\times$ Entrepreneur & & & $0.022(0.008)^{* * *}$ & $0.024(0.009)^{* *}$ \\
\hline $\mathrm{R}^{2}$ within & 0.031 & 0.424 & 0.355 & 0.359 \\
\hline $\mathrm{R}^{2}$ between & 0.234 & 0.616 & 0.584 & 0.380 \\
\hline $\mathrm{R}^{2}$ overall & 0.182 & 0.595 & 0.534 & 0.336 \\
\hline Observations & 11,180 & 81,411 & 92,591 & 92,591 \\
\hline Individuals & 2975 & 15,174 & 16,293 & 16,293 \\
\hline \multicolumn{5}{|l|}{ B. Cognitive ability included } \\
\hline Education & $0.088(0.010)^{* * *}$ & $0.065(0.003)^{* * *}$ & $0.063(0.003)^{* * *}$ & \\
\hline Entrepreneur & & & $-1.233(0.555)^{* *}$ & $-0.631(0.202)^{* * *}$ \\
\hline Education $\times$ Entrepreneur & & & $0.017(0.008)^{* *}$ & $0.020(0.010)^{* *}$ \\
\hline Ability & $0.092(0.027)^{* * *}$ & $0.089(0.009)^{* * *}$ & $0.071(0.009)^{* * *}$ & \\
\hline Ability $\times$ Entrepreneur & & & $0.047(0.026)^{*}$ & $0.055(0.032)^{*}$ \\
\hline $\mathrm{R}^{2}$ within & 0.034 & 0.429 & 0.361 & 0.363 \\
\hline $\mathrm{R}^{2}$ between & 0.251 & 0.651 & 0.617 & 0.401 \\
\hline $\mathrm{R}^{2}$ overall & 0.180 & 0.605 & 0.542 & 0.340 \\
\hline Observations & 9838 & 71,225 & 81,063 & 81,063 \\
\hline Individuals & 2394 & 11,399 & 12,182 & 12,182 \\
\hline
\end{tabular}

Notes: *p $<0.10$; ** $\mathrm{p}<0.05 ;{ }^{* * *} \mathrm{p}<0.01$; Cluster-robust standard errors in parentheses. 
Table 3

The relationship between formal education and income (dependent variable: logarithm of annual income); Models including job control and triple interaction.

\begin{tabular}{|c|c|c|}
\hline & $\begin{array}{l}\text { (1) } \\
\text { All (RE) }\end{array}$ & $\begin{array}{l}(2) \\
\text { All (FE) }\end{array}$ \\
\hline \multicolumn{3}{|l|}{ A. Cognitive ability not included } \\
\hline$\overline{\text { Education (demeaned) }}$ & $0.060(0.003)^{* * *}$ & \\
\hline Entrepreneur & $1.002(0.474)^{* *}$ & $-0.183(0.148)$ \\
\hline Education (demeaned) $\times$ Entrepreneur & $0.030(0.010)^{* * *}$ & $0.031(0.011)^{* * *}$ \\
\hline Job control & $0.019(0.003)^{* * *}$ & $0.006(0.003)^{*}$ \\
\hline Job control $\times$ Education (demeaned) & $0.006(0.001)^{* * *}$ & $0.003(0.002)^{*}$ \\
\hline Job control $\times$ Entrepreneur & $-0.010(0.014)$ & $-0.001(0.015)$ \\
\hline Job control $\times$ Entrepreneur $\times$ Education (demeaned) & $-0.012(0.007)^{*}$ & $-0.009(0.007)$ \\
\hline $\mathrm{R}^{2}$ within & 0.362 & 0.365 \\
\hline $\mathrm{R}^{2}$ between & 0.589 & 0.386 \\
\hline $\mathrm{R}^{2}$ overall & 0.541 & 0.339 \\
\hline Observations & 90,324 & 90,324 \\
\hline Individuals & 16,031 & 16,031 \\
\hline \multicolumn{3}{|l|}{ B. Cognitive ability included } \\
\hline Education (demeaned) & $0.061(0.003)^{* * *}$ & \\
\hline Entrepreneur & $-0.593(0.268)^{* *}$ & $-0.309(0.186)^{*}$ \\
\hline Education (demeaned) $\times$ Entrepreneur & $0.030(0.011)^{* * *}$ & $0.031(0.012)^{* * *}$ \\
\hline Job control & $0.018(0.003)^{* * *}$ & $0.007(0.004)^{* *}$ \\
\hline Job control $\times$ Education (demeaned) & $0.004(0.002)^{* * *}$ & $0.001(0.002)$ \\
\hline Job control $\times$ Entrepreneur & $-0.023(0.015)$ & $-0.011(0.015)$ \\
\hline Job control $\times$ Entrepreneur $\times$ Education (demeaned) & $-0.013(0.007)^{*}$ & $-0.009(0.008)$ \\
\hline Ability & $0.063(0.009)^{* * *}$ & \\
\hline Ability $\times$ entrepreneur & $0.051(0.027)^{*}$ & $0.064(0.033)^{*}$ \\
\hline $\mathrm{R}^{2}$ within & 0.367 & 0.370 \\
\hline $\mathrm{R}^{2}$ between & 0.622 & 0.408 \\
\hline $\mathrm{R}^{2}$ overall & 0.548 & 0.342 \\
\hline Observations & 79,220 & 79,220 \\
\hline Individuals & 12,037 & 12,037 \\
\hline
\end{tabular}

Notes: *p $<0.10 ; * * \mathrm{p}<0.05 ; * * * \mathrm{p}<0.01$; Cluster-robust standard errors in parentheses.

3.2 percentage-points in the fixed-effects specification). The higher returns to education for entrepreneurs seem to hold mainly for those not having employees. Additional Wald tests, however, do not reveal significantly higher returns to education for entrepreneurs without employees than for those with employees $\left(\chi^{2}=0.49, \mathrm{p}=0.49\right.$ in the random-effects analysis; $\chi^{2}=2.05, \mathrm{p}=0.15$ in the fixed-effects analysis). The regressions including the cognitive ability measure lead to similar conclusions (panel B).

To explore whether job control can explain the significantly higher returns to education for the entrepreneurs without employees compared to employees, we amend the models with job control and the relevant interactions. Table 5, both in panel A and panel B, shows that the coefficients of Education $\times$ Entrepreneur without employees and Education $\times$ Entrepreneur with employees are not lower than without job control. Hence, we do not find evidence for mediated moderation of job control in explaining the returns to education for entrepreneurs with and without employees versus wageworkers.

\subsection{Additional analyses}

Job control. Our study improves upon the Van Praag et al. (2013) study by using a measure of job control rather than perceived control of the environment. Given the limited evidence for mediated moderation with our measure, we also test for mediated moderation with a measure that is similar to the one used by Van Praag et al. (2013). Replacement of our job control measure in Tables 3 and 5 with a measure for internal locus of control (Cronbach's alpha $=0.84),{ }^{8}$ however, does not yield different conclusions. In general, we do not find evidence for a mediation effect of the Education $\times$ Entrepreneur interaction that runs via locus of control. For example, after replacing job control with locus of control in Table 3, the coefficients for Education $\times$ Entrepreneur are $0.022(\mathrm{p}<0.01$; RE) and 0.025 ( $\mathrm{p}<0.01$; FE) without cognitive ability included, and 0.018 ( $\mathrm{p}<0.05$; RE) and 0.021 ( $\mathrm{p}<0.05$; FE) with cognitive ability included). Hence, we do not find support for a mediating effect because the coefficients of the Education $\times$ Entrepreneur interaction do not change.

\footnotetext{
8 The measure for locus of control reflects the average of answers (1 - Strongly Disagree to 7 - Strongly Agree) to the following items: (a) I have little control over the things that happen to me; (b) There is really no way I can solve some of problems I have; (c) There is little I can do to change many of the important things in my life; (d) I often feel helpless in dealing with the problems of life; (e) Sometimes I feel that I'm being pushed around in life; (f) What happens to me in the future mostly depends on me; (g) I can do just about anything I really set my mind to do. Items (f) and (g) are reverse-coded. These questions were asked in 2003, 2004, 2007, 2011 and 2015. In our analyses, we use for each individual the average value across these years.
} 
Table 4

The relationship between formal education and income (dependent variable: logarithm of annual income); Stratified analysis of entrepreneurs without and with employees.

\begin{tabular}{|c|c|c|c|c|}
\hline & $\begin{array}{l}\text { (1) } \\
\text { Entrepreneurs without } \\
\text { employees (RE) }\end{array}$ & $\begin{array}{l}\text { (2) } \\
\text { Entrepreneurs with } \\
\text { employees (RE) }\end{array}$ & $\begin{array}{l}\text { (3) } \\
\text { All (RE) }\end{array}$ & $\begin{array}{l}(4) \\
\text { All (FE) }\end{array}$ \\
\hline \multicolumn{5}{|l|}{ A. Cognitive ability not included } \\
\hline$\overline{\text { Education }}$ & $0.089(0.011)^{* * *}$ & $0.096(0.011)^{* * *}$ & $0.061(0.003)^{* * *}$ & \\
\hline Entrepreneur without employees & & & $-0.813(0.219)^{* * *}$ & $-0.572(0.240)^{* *}$ \\
\hline Entrepreneur with employees & & & $2.978(0.443)^{* * *}$ & $3.731(0.485)^{* * *}$ \\
\hline $\begin{array}{l}\text { Education } \times \text { Entrepreneur without } \\
\text { employees }\end{array}$ & & & $0.027(0.010)^{* * *}$ & $0.032(0.011)^{* * *}$ \\
\hline Education $\times$ Entrepreneur with employees & & & $0.018(0.009)^{*}$ & $0.014(0.011)$ \\
\hline $\mathrm{R}^{2}$ within & 0.042 & 0.039 & 0.360 & 0.363 \\
\hline $\mathrm{R}^{2}$ between & 0.219 & 0.229 & 0.591 & 0.380 \\
\hline $\mathrm{R}^{2}$ overall & 0.184 & 0.176 & 0.541 & 0.338 \\
\hline Observations & 6252 & 4921 & 92,584 & 92,584 \\
\hline Individuals & 2162 & 1431 & 16,293 & 16,293 \\
\hline \multicolumn{5}{|l|}{ B. Cognitive ability included } \\
\hline Education & $0.084(0.012)^{* * *}$ & $0.096(0.012)^{* * *}$ & $0.063(0.003)^{* * *}$ & \\
\hline Entrepreneur without employees & & & $-0.728(0.023)^{* * *}$ & $-0.521(0.256)^{* *}$ \\
\hline Entrepreneur with employees & & & $3.315(0.484)^{* * *}$ & $3.780(0.514)^{* * *}$ \\
\hline $\begin{array}{l}\text { Education } \times \text { Entrepreneur without } \\
\text { employees }\end{array}$ & & & $0.021(0.010)^{* *}$ & $0.026(0.011)^{* *}$ \\
\hline Education $\times$ Entrepreneur with employees & & & $0.014(0.010)$ & $0.013(0.012)$ \\
\hline Ability & $0.082(0.037)^{* *}$ & $0.092(0.037)^{* *}$ & $0.070(0.009)^{* * *}$ & \\
\hline Ability $\times$ Entrepreneur without employees & & & $0.050(0.033)$ & $0.061(0.038)$ \\
\hline Ability $\times$ Entrepreneur with employees & & & $0.051(0.035)$ & $0.063(0.042)$ \\
\hline $\mathrm{R}^{2}$ within & 0.046 & 0.043 & 0.365 & 0.368 \\
\hline $\mathrm{R}^{2}$ between & 0.229 & 0.234 & 0.625 & 0.401 \\
\hline $\mathrm{R}^{2}$ overall & 0.186 & 0.170 & 0.549 & 0.342 \\
\hline Observations & 5480 & 4352 & 81,057 & 81,057 \\
\hline Individuals & 1774 & 1161 & 12,182 & 12,182 \\
\hline
\end{tabular}

Notes: *p $<0.10 ; * * \mathrm{p}<0.05 ; * * * \mathrm{p}<0.01$; Cluster-robust standard errors in parentheses.

Assessing mediated moderation. The evidence for mediated moderation is currently stemming from models including the triple interaction term Job control $\times$ Entrepreneur $\times$ Education (Tables 3 and 5). The triple interaction term implies a conditional interpretation of the Education $\times$ Entrepreneur interaction, which could limit the comparison between the findings in Tables 3 and 5 . We therefore also report regression results from models without the triple interaction. In doing so, we follow the recommendation of Fairchild and MacKinnon (2009) that “... there is no need to model the XMZ interaction if there is no hypothesis to support its estimation." The results are reported in the Appendix (Tables 3A and 5A). The coefficient of Education $\times$ Entrepreneur (Table 3A, panel A) diminishes by $14 \%$ in the random-effects specification (compared to $34 \%$ in Van Praag et al., 2013) . ${ }^{9}$ This decrease is much smaller in the fixed-effects specification (3\%; compared to $25 \%$ in Van Praag et al., 2013) ${ }^{10}$. The inclusion of cognitive ability to the model specification also does not provide evidence in favor of mediated moderation.

Returns to education for entrepreneurs with and without employees. By exploring whether the returns to education are different for entrepreneurs with and without employees, we found that the higher returns to education for entrepreneurs compared to wage workers hold mainly for entrepreneurs with employees. By analyzing the variance of earnings over time, following the strategy put forward by Van Praag et al. (2013), we here explore whether the earnings of entrepreneurs with or without employees reflect businesses with different risk-profiles. From Table 1, we can already conclude that the variance in earnings is highest among the entrepreneurs without employees. This is confirmed when we use the variance of the residuals (over time) of the income regressions (Table 2, Model 3) as an indicator of risk. This variance over time is significantly higher among the entrepreneurs without employees (0.48) than among wageworkers $(0.35 ; \mathrm{p}=0.01)$. There is no significant difference between wageworkers and the entrepreneurs with employees $(0.43$; $\mathrm{p}=0.23)$, and no significant difference between entrepreneurs with and without employees $(\mathrm{p}=0.56)$. Relatedly, we also verified whether higher educated individuals are more likely to venture into projects with a higher expected risk-return profile because of having better outside (salaried) opportunities. When regressing the variance of the residuals on education and the control variables, the regression coefficient for education is not significant for wageworkers $(b=0.001 ; p=0.99)$, entrepreneurs without employees $(b=0.03 ; p=0.40)$, and entrepreneurs with employees $(b=-0.016 ; p=0.66)$. Therefore, in line with Van Praag et al. (2013), we rule

\footnotetext{
${ }^{9} 34 \%$ is obtained by comparing the RE coefficients of the Education $\times$ Entrepreneur interaction in Tables 3 and 5 (panel A) in Van Praag et al. (2013).

${ }^{10} 25 \%$ is obtained by comparing the FE coefficients of the Education $\times$ Entrepreneur interaction in Tables 3 and 5 (panel A) in Van Praag et al. (2013).
} 
Table 5

The relationship between formal education and income (dependent variable: log of annual income); Models including job control and triple interaction; Stratified analysis of entrepreneurs without and with employees.

\begin{tabular}{|c|c|c|}
\hline & (1) All (RE) & (2) All (FE) \\
\hline \multicolumn{3}{|l|}{ A. Cognitive ability not included } \\
\hline$\overline{\text { Education }}$ & $0.060(0.001)^{* * *}$ & \\
\hline Entrepreneur without employees & $-0.470(0.185)^{* *}$ & $-0.158(0.192)$ \\
\hline Entrepreneur with employees & $3.118(0.418)^{* * *}$ & $3.890(0.457)^{* * *}$ \\
\hline Education $\times$ Entrepreneur without employees & $0.036(0.011)^{* * *}$ & $0.043(0.013)^{* * *}$ \\
\hline Education $\times$ Entrepreneur with employees & $0.026(0.015)^{*}$ & $0.018(0.016)$ \\
\hline Job control & $0.021(0.003)^{* * *}$ & $0.008(0.003)^{* *}$ \\
\hline Job control $\times$ Education & $0.006(0.001)^{* * *}$ & $0.003(0.002)^{*}$ \\
\hline Job control $\times$ Entrepreneur without employees & $-0.025(0.018)$ & $-0.009(0.019)$ \\
\hline Job control $\times$ Entrepreneur with employees & $-0.004(0.022)$ & $-0.001(0.023)$ \\
\hline Job control $\times$ Entrepreneur without empl. $\times$ Education (demeaned) & $-0.012(0.008)$ & $-0.012(0.009)$ \\
\hline Job control $\times$ Entrepreneur with empl. $\times$ Education (demeaned) & $-0.011(0.011)$ & $-0.003(0.011)$ \\
\hline $\mathrm{R}^{2}$ within & 0.367 & 0.370 \\
\hline $\mathrm{R}^{2}$ between & 0.596 & 0.386 \\
\hline $\mathrm{R}^{2}$ overall & 0.548 & 0.341 \\
\hline Observations & 90,318 & 90,318 \\
\hline Individuals & 16,031 & 16,031 \\
\hline \multicolumn{3}{|l|}{ B. Cognitive ability included } \\
\hline$\overline{\text { Education }}$ & $0.062(0.003)^{* * *}$ & \\
\hline Entrepreneur without employees & $-0.467(0.209)^{* *}$ & $-0.150(0.206)$ \\
\hline Entrepreneur with employees & $3.301(0.455)^{* * *}$ & $3.946(0.487)^{* * *}$ \\
\hline Education $\times$ Entrepreneur without employees & $0.039(0.013)^{* * *}$ & $0.045(0.014)^{* * *}$ \\
\hline Education $\times$ Entrepreneur with employees & $0.025(0.016)$ & $0.019(0.017)$ \\
\hline Job control & $0.020(0.003)^{* * *}$ & $0.009(0.004)^{* *}$ \\
\hline Job control $\times$ Education & $0.004(0.002)^{* * *}$ & $0.001(0.002)$ \\
\hline Job control $\times$ Entrepreneur without employees & $-0.034(0.020)^{*}$ & $-0.017(0.021)$ \\
\hline Job control $\times$ Entrepreneur with employees & $-0.021(0.023)$ & $-0.014(0.024)$ \\
\hline Job control $\times$ Entrepreneur without empl. $\times$ Education (demeaned) & $-0.016(0.009)^{*}$ & $-0.014(0.010)$ \\
\hline Job control $\times$ Entrepreneur with empl. $\times$ Education (demeaned) & $-0.010(0.011)$ & $-0.003(0.012)$ \\
\hline Ability & $0.062(0.008)^{* * *}$ & \\
\hline Ability $\times$ Entrepreneur without employees & $0.060(0.036)^{*}$ & $0.073(0.042)^{*}$ \\
\hline Ability $\times$ Entrepreneur with employees & $0.046(0.036)$ & $0.068(0.044)$ \\
\hline $\mathrm{R}^{2}$ within & 0.372 & 0.375 \\
\hline $\mathrm{R}^{2}$ between & 0.629 & 0.407 \\
\hline $\mathrm{R}^{2}$ overall & 0.555 & 0.345 \\
\hline Observations & 79,215 & 79,215 \\
\hline Individuals & 12,037 & 12,037 \\
\hline
\end{tabular}

Notes: *p $<0.10 ; * * \mathrm{p}<0.05 ; * * * \mathrm{p}<0.01$; Cluster-robust standard errors in parentheses.

out the possibility of a risk premium as an explanation behind the higher returns to education for both types of entrepreneurs compared to wageworkers.

\section{Conclusion}

The present study aimed to replicate the findings of Van Praag et al. (2013) that the returns to education in terms of income are higher for entrepreneurs than for employees. Using a dataset from a different country (Australia instead of the US) and time period (2005-2017 instead of 1979-2000), we were able to replicate the original findings. The magnitude of the effects is similar across both studies, but in some model specifications our estimates are somewhat larger. However, we show that these results mainly apply to entrepreneurs without employees. The income of an entrepreneur with employees is not only influenced by the entrepreneur's own human capital, but also depends to some extent on the performance (and level of education) of its employees. This is not the case for entrepreneurs who work on their own account and who may be better able to adapt their production such that they yield higher returns to their assets. Van Praag et al. (2013) present evidence that the relatively high returns to education for entrepreneurs are explained by the level of control in their job. In our analyses, with an arguably better measure for job control, we find support for a partial mediating effect in one model specification only. In all other models, we do not find evidence for a mediating effect of job control. Our robustness check using the same measure for job control as Van Praag et al. (2013) does not provide evidence for mediation either.

Based on our findings, we concur with Van Praag et al. (2013) that it may be worthwhile to stimulate individuals with higher levels of formal education to become an entrepreneur and to encourage individuals with entrepreneurial intentions to complete formal education first. In terms of possible mechanisms explaining the higher returns to education for entrepreneurs (and mainly those not having employees), our findings do not support the idea that more job control should be assigned to workers as a mechanism to obtain higher returns to education. Van Praag et al. (2013) suggest that their study provides a starting point for the development of a new theory of personal control as an explanation for the higher returns to education for entrepreneurs compared to employees. However, our study 
suggests that the development of such a new theory may be of limited value since we do not find support for a mediating role of personal control.

We note that our evidence stems from a sample that is representative of all Australian households (the sampling unit is the household and members of the households are interviewed) with an age range of $16-64$ years. ${ }^{11}$ In terms of the generalizability of our results to other (developed) countries, the composition of the group of entrepreneurs in the labor force seems a relevant factor to take into consideration. While we already distinguish between the self-employed with and without employees in our study, results will particularly generalize to developed countries that are relatively similar to Australia in terms of, for example, growth aspirations, innovativeness or start-up motivations (Steffens and Omaravo, 2019).

The present study provides several directions for future research. First, future studies may delve into the question what mechanisms (other than personal control in one's job) can explain the higher returns to education for entrepreneurs compared to wageworkers particularly in Australia in the time-frame analyzed. Importantly, one could investigate the impact of individual and occupational characteristics (as well as their interaction). Second, we encourage researchers to replicate our findings regarding the different returns to education for entrepreneurs with and without employees using data from other time-periods and countries, possibly by adopting a sound instrumental variable approach (Block et al., 2013). Third, we encourage researchers to investigate whether returns to other important elements of human capital such as mental and physical health differ for entrepreneurs and employees. Good health is essential to run a business successfully (Gielnik et al., 2012; Rietveld et al., 2015; Hessels et al., 2018) and running a business successfully may lead to good health (Torrès and Thurik, 2019). More importantly, the income of entrepreneurs is likely to depend more directly on the ability to work well compared to the earnings of employees.

In conclusion, we validate the important role of educational attainment in the earnings equations for entrepreneurship. However, we also conclude - contrary to Van Praag et al. (2013) - that the "entrepreneurship returns puzzle" has not been explained yet. Hence, although there are several benefits to higher levels of job control, such as experiencing less work-related stress (Hessels et al., 2017), our findings based on Australian data from 2005 to 2017 do not support the idea that more job control should be assigned to workers as a mechanism to obtain higher returns to education.

\section{Declaration of competing interest}

The authors have no conflict of interests.

Jolanda Hessels on behalf of the author team.

\section{Acknowledgments}

This paper uses unit record data from the Household, Income and Labour Dynamics in Australia (HILDA) Survey. The HILDA Project was initiated and is funded by the Australian Government Department of Social Services (DSS) and is managed by the Melbourne Institute of Applied Economic and Social Research (Melbourne Institute). The findings and views reported in this paper are those of the authors and should not be attributed to either DSS or the Melbourne Institute. Roy Thurik is member of the LabEx Entrepreneurship (University of Montpellier, France) funded by the French government (Labex Entreprendre, ANR-10-Labex-11-01).

\section{Appendix}

Table 3A

The relationship between formal education and income (dependent variable: logarithm of annual income); Models including job control; excluding triple interaction.

\begin{tabular}{lcc}
\hline & \multicolumn{1}{c}{$(1)$} & $(2)$ \\
& All (RE) & All (FE) \\
\hline A. Cognitive ability not included & & \\
Education & $0.060(0.003)^{* * *}$ & $-0.488(0.180)^{* * *}$ \\
Entrepreneur & $0.750(0.478)$ & $0.023(0.009)^{* * *}$ \\
Education $\times$ Entrepreneur & $0.019(0.008)^{* * *}$ & $-0.023(0.021)$ \\
Job control & $-0.041(0.018)^{* *}$ & $0.002(0.002)$ \\
Job control $\times$ Education & $0.005(0.001)^{* * *}$ & $0.002(0.014)$ \\
Job control $\times$ Entrepreneur & $-0.006(0.014)$ & 0.365 \\
$\mathrm{R}^{2}$ within & 0.362 & 0.386 \\
$\mathrm{R}^{2}$ between & 0.589 & 0.339 \\
$\mathrm{R}^{2}$ overall & 0.541 & 90,324 \\
Observations & 90,324 & 16,031 \\
Individuals & 16,031 & \\
& & (continued on next page)
\end{tabular}

\footnotetext{
${ }^{11}$ For demographic variables the representativeness is high; income estimates have been reported to be higher than in the Australian Bureau of Statistics Survey of Income and Housing (Summerfield et al., 2019).
} 
Table 3A (continued)

\begin{tabular}{|c|c|c|}
\hline & $\begin{array}{l}\text { (1) } \\
\text { All (RE) }\end{array}$ & $\begin{array}{l}(2) \\
\text { All (FE) }\end{array}$ \\
\hline \multicolumn{3}{|l|}{ B. Cognitive ability included } \\
\hline Education & $0.061(0.003)^{* * *}$ & \\
\hline Entrepreneur & $-0.829(0.279)^{* * *}$ & $-0.614(0.218)^{* * *}$ \\
\hline Education $\times$ Entrepreneur & $0.018(0.008)^{* *}$ & $0.023(0.010)^{* *}$ \\
\hline Job control & $-0.021(0.020)$ & $-0.003(0.022)$ \\
\hline Job control $\times$ Education & $0.003(0.002)^{* *}$ & $0.001(0.002)$ \\
\hline Job control $\times$ Entrepreneur & $-0.018(0.015)$ & $-0.007(0.015)$ \\
\hline Ability & $0.063(0.009)^{* *}$ & \\
\hline Ability $\times$ Entrepreneur & $0.051(0.027)^{*}$ & $0.065(0.033)^{*}$ \\
\hline $\mathrm{R}^{2}$ within & 0.367 & 0.370 \\
\hline $\mathrm{R}^{2}$ between & 0.622 & 0.408 \\
\hline $\mathrm{R}^{2}$ overall & 0.547 & 0.342 \\
\hline Observations & 79,220 & 79,220 \\
\hline Individuals & 12,037 & 12,037 \\
\hline
\end{tabular}

Notes: *p $<0.10 ; * * \mathrm{p}<0.05 ; * * * \mathrm{p}<0.01$; Cluster-robust standard errors in parentheses.

Table 5A

The relationship between formal education and income (dependent variable: log of annual income); Models including job control; excluding triple interaction; Stratified analysis of entrepreneurs without and with employees.

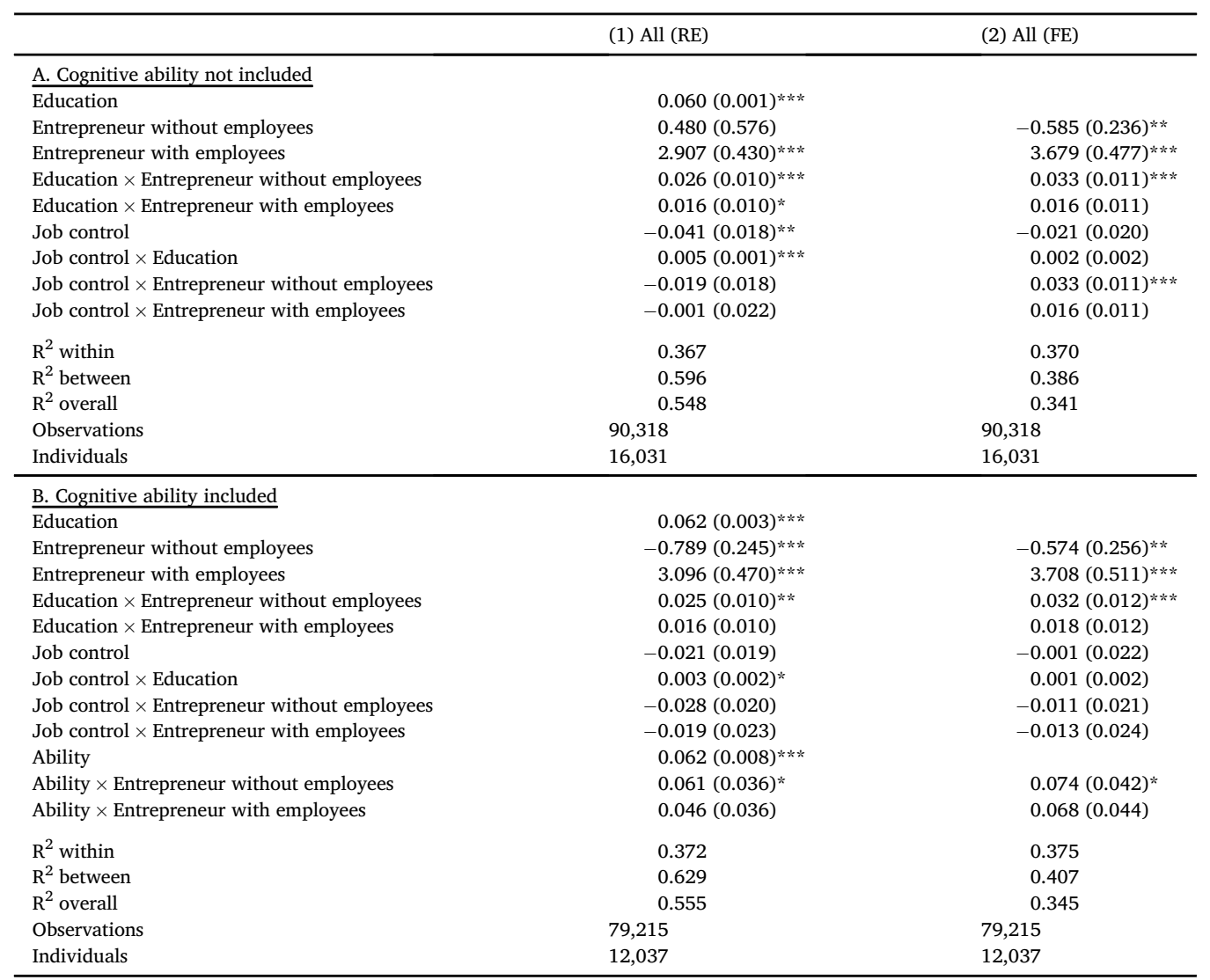

Notes: *p $<0.10 ; * * \mathrm{p}<0.05 ; * * * \mathrm{p}<0.01$; Cluster-robust standard errors in parentheses.

\section{References}

Block, J.H., Hoogerheide, L., Thurik, R., 2013. Education and entrepreneurial choice: an instrumental variables analysis. Int. Small Bus. J. 31 (1), 23-33. Deaton, A., 2000. The Analysis of Household Surveys. Johns Hopkins University Press, Washington, DC.

DiRenzo, M.S., Greenhaus, J.H., Weer, C.H., 2011. Job level, demands, and resources as antecedents of work-family conflict. J. Vocat. Behav. 78 (2), 305-314. Fairchild, A.J., MacKinnon, D.P., 2009. A general model for testing mediation and moderation effects. Prev. Sci. 10 (2), 87-99.

Gielnik, M.M., Zacher, H., Frese, M., 2012. Focus on opportunities as a mediator of the relationship between business owners' age and venture growth. J. Bus. Ventur. 27 (1), 127-142. 
Grande, J., Madsen, E.L., Borch, O.J., 2011. The relationship between resources, entrepreneurial orientation and performance in farm-based ventures. Entrep. Reg. Dev. 23 (3-4), 89-111.

Hartog, J., Van Praag, M., Van Der Sluis, J., 2010. If you are so smart, why aren't you an entrepreneur? Returns to cognitive and social ability: entrepreneurs versus employees. J. Econ. Manag. Strategy 19 (4), 947-989.

Hébert, R.F., Link, A.N., 2009. A History of Entrepreneurship. Routledge, London/New York.

Hessels, J., Rietveld, C.A., Thurik, A.R., van der Zwan, P., 2018. Depression and entrepreneurial exit. Acad. Manag. Perspect. 32 (3), $323-339$.

Hessels, J., Rietveld, C.A., van der Zwan, P., 2017. Self-employment and work-related stress: the mediating role of job control and job demand. J. Bus. Ventur. 32 (2), $178-196$.

Karasek, R., Brisson, C., Kawakami, N., Houtman, I., Bongers, P., Amick, B., 1998. The Job Content Questionnaire (JCQ): an instrument for internationally comparative assessments of psychosocial job characteristics. J. Occup. Health Psychol. 3 (4), 322-355.

Lazear, E.P., 2005. Entrepreneurship. J. Lab. Econ. 23 (4), 649-680.

Leigh, A., Ryan, C., 2005. Estimating returns to education: Three natural experiment techniques compared. The Australian National University Centre for Economic Policy Research Discussion Paper No. 493. ANU, Canberra, Australia:

Leigh, A., Ryan, C., 2008. Estimating returns to education using different natural experiment techniques. Econ. Educ. Rev. 27 (2), 149-160.

Rietveld, C.A., Van Kippersluis, H., Thurik, A.R., 2015. Self-employment and health: barriers or benefits? Health Econ. 24 (10), 1302-1313.

Smith, C.S., Tisak, J., Hahn, S.E., Schmieder, R.A., 1997. The measurement of job control. J. Organ. Behav. 18 (3), $225-237$.

Sorgner, A., Fritsch, M., Kritikos, A., 2017. Do entrepreneurs really earn less? Small Bus. Econ. 49 (2), $251-272$.

Summerfield, M., Bevitt, A., Fok, Y.K., Hahn, M., La, N., Macalalad, N., O’Shea, M., Watson, N., Wilkins, R., Wooden, M., 2019. HILDA user manual - Release 17. Melbourne Institute of Applied Economic and Social Research. University of Melbourne.

Steffens, P.R., Omarova, A., 2019. Global Entrepreneurship Monitor (GEM)-2017/18 Australian National Report. Available at: https://eprints.qut.edu.au/127058/1/ GEM\%20AUS\%20Report\%20CLIENT\%20corrected.pdf.

Torrès, O., Thurik, R., 2019. Small business owners and health. Small Bus. Econ. 53 (2), 311-321.

Van Praag, M., van Witteloostuijn, A., van der Sluis, J., 2013. The higher returns to formal education for entrepreneurs versus employees. Small Bus. Econ. 40 (2), 375-396.

Watson, N., Wooden, M., 2012. The HILDA Survey: a case study in the design and development of a successful household panel study. Longit. Life Course Stud. 3 (3), 369-381.

Wooden, M., 2013. In: The Measurement of Cognitive Ability in Wave 12 of the HILDA Survey. Melbourne Institute Working Paper Series, Working Paper No. 44/13. University of Melbourne.

Wu, C.H., 2016. Personality change via work: a job demand-control model of Big-five personality changes. J. Vocat. Behav. 92 (1), $157-166$. 